\title{
Chronic liver disease in transfusion-dependent thalassaemia: hepatitis B virus marker studies
}

\author{
S DE VIRGILIIS, G FIORELLI, * S FARGION, * G CORNACCHIA, G SANNA, \\ P COSSU, V MURGIA, AND A CAO
}

From the 2nd Pediatric Clinic, University of Cagliari, Sardinia, and the *3rd Clinic of Medicine, University of Milano, Italy

SUMMARY The systematic screening of 253 children with transfusion-dependent homozygous $\beta$-thalassaemia revealed a high incidence of hepatitis $B$ virus markers. The highest frequencies of hepatitis B surface antigen (HBsAg) and antibody to hepatitis B core antigen (anti-HBc) were found in the group of patients with the smallest number of transfusions, while the highest frequency of antibody to hepatitis B surface antigen (anti-HBs) was detected in the patients who had had the largest number of transfusions. Follow-up of these patients showed $(a)$ a high incidence of acute hepatitis B, which was mainly subclinical; (b) normal hepatitis B surface antigen clearance and normal antibody to hepatitis B surface development; and (c) a high frequency of increased transaminase values for over six months. In all the subjects with persistently high transaminase, histological examination revealed chronic persistent hepatitis or chronic active hepatitis. Apart from two cases of chronic active hepatitis with no B virus markers, and two cases of chronic persistent hepatitis with $\mathrm{HBsAg}$ and anti-HBc in the serum, all these subjects were anti-HBs positive but $\mathrm{HBsAg}$ and anti-HBc negative.

Chronic hepatitis occurs very frequently in children with transfusion-dependent thalassaemia in the Mediterranean area, including Sardinia. ${ }^{1-6}$ Viral agents implicated in transfusional hepatitis ${ }^{3} 67$ and iron overload, ${ }^{8}$ resulting from the high transfusion regimen are considered to be the main causes. Among the hepatitis viruses, a predominant role is ascribed to hepatitis B virus (HBV), while little, if any role, has been given to the A virus.?

In the United States, it has recently been shown that the non-A, non-B virus(es) seem to cause transfusional hepatitis even more frequently than HBV. ${ }^{9}$ However, there are no data on the incidence of this viral infection in the Mediterranean area.

To elucidate the role of $\mathrm{HBV}$ in the development of chronic liver disease in 253 children with transfusion-dependent thalassaemia major, we carried out: (a) a survey of the prevalence of $\mathrm{HBV}$ markers; (b) a two-year follow-up of HBV markers and liver function tests; and (c) liver biopsy studies in patients with persistently increased transaminase levels.

Received for publication 8 April 1980

\section{Patients and methods}

This study concerns 253 Sardinian children aged 1 to 14 years with homozygous $\beta^{\circ}$-thalassaemia, who were followed in the 2nd Paediatric Department of Cagliari University from September 1975 to November 1977 . The diagnosis of homozygous $\beta^{\circ}$-thalassaemia was made on the basis of haemoglobin electrophoresis and globin chain synthesis analysis. ${ }^{10}$

For the past three years these patients have been regularly transfused with packed red cells every three to four weeks in order to keep their $\mathrm{Hb}$ pretransfusion levels above $9 \mathrm{~g} / \mathrm{dl}$. They had chelation therapy with intramuscular desferrioxamine-B (750 $\mathrm{mg} /$ day at age 3-9 years and $1 \mathrm{~g} /$ day at $9+$ years for six days a week). Previously, they received sporadic transfusions with whole blood, and chelation therapy was administered in low doses at irregular intervals.

Hepatitis B surface antigen (HBsAg) testing in blood donors was performed by passive haemagglutination.

In all patients, liver function tests were carried out at regular intervals for two years. Serum aspartate and alanine aminotransferase (SGPT and SGOT) 
were determined monthly; alkaline phosphatase, $\gamma$-glutamyl-transpeptidase, pseudocholinesterase, serum protein electrophoresis, and prothrombin time (normotest) were performed every three months. The enzymatic tests were carried out with standard kits (Biochemia, Boehringer, Mannheim). Serum protein electrophoresis was carried out on gelatinised cellulose acetate strips (Chemetron, Milano). Normotest, which is a standardised coagulation test sensitive to clotting factors II, VII, and X, was performed according to the manufacturer's instructions (Nycegard, Oslo).

HBsAg and antibody to hepatitis B surface antigen (anti-HBs) were determined every three months by a solid-phase radioimmunoassay (RIA) (Ausria II-125 and Ausab, Abbott). Patients found to be HBsAg positive were subsequently tested monthly unless they became $\mathrm{HBsAg}$ negative. In 40 randomly selected subjects, these determinations were performed monthly.

Antibody to hepatitis B core antigen (anti-HBc), determined by indirect immunofluorescence on a core-rich human liver with no fixed anti-HBc (supplied by Professor Desmet), was performed as a screening test in all patients. Successive control tests were carried out in $\mathrm{HBs} \mathrm{Ag}$ positive patients and in those with clinical or biochemical signs of liver disease. One hundred and fifty-six Sardinian children of the same age and from similar income levels acted as controls.

Fifty-two patients, with three times normal transaminase values for over six months, had percutaneous liver biopsy performed with a Menghini needle. The liver tissue was processed by routine histological techniques. The diagnosis of chronic hepatitis was made on the basis of the criteria established by De Groote et al. ${ }^{11}$ and subsequently modified by the International Group for the Study of Liver Diseases. ${ }^{12}$

\section{Results}

INCIDENCE AND FOLLOW-UP OF HBV

MARKERS

The prevalence of HBV markers in the 253 regularly transfused thalassaemia major patients is shown in
Table 1. The patients are divided into three groups according to the units of blood received. The highest prevalence of HBsAg was found in the group of patients with the smallest number of transfusions, while the highest prevalence of anti-HBs is in those who had the largest number of blood transfusions. The behaviour of anti-HBc was similar to that of HBsAg. Anti-HBc was found in seven subjects: in four it was associated with $\mathrm{HBsAg}$ and in three it was the only viral marker detected.

On follow-up of the four patients with both anti$\mathrm{HBc}$ and $\mathrm{HBsAg}$, two, persistently positive for these markers, developed chronic persistent hepatitis (CPH), and two had clearance of both markers in 18 and 24 months, respectively, followed by the appearance of anti-HBs. The three cases showing anti-HBc as the only marker had clearance of this marker in six to eight months and developed anti-HBs positivity.

The HBsAg positive cases cleared in two to four months and developed anti-HBs, which was present throughout follow-up. Those with only anti-HBs positivity had persistence of this antibody for the two-year follow-up period.

After 12 months' follow-up one subject with persistent anti-HBs positivity developed both HBsAg and anti-HBc, persisting for six months. The anti-HBs positivity in this subject persisted for the whole two years. One month after the appearance of $\mathrm{HBsAg}$ and anti-HBc, clinical acute hepatitis with SGPT $>250 \mathrm{mU} / \mathrm{ml}$ developed. Another patient with persistent anti-HBs positivity developed HBsAg and anti-HBc while anti-HBs disappeared. During the six-month follow-up, HBsAg and anti$\mathrm{HBC}$ remained positive while anti-HBs was persistently absent. This subject showed no clinical or biochemical manifestations of liver disease and, particularly, no signs of immunocomplex disorders. Unfortunately, HBsAg subtype characterisation was not performed.

HBV MARKERS IN ACUTE CLINICAL OR SUBCLINICAL HEPATITIS

The monthly determination of $\mathrm{HBV}$ markers in a randomly selected group of subjects enabled us to follow up the development of these markers in 35

Table $1 \mathrm{HBs} A \mathrm{~g}$, anti-HBs, and anti-HBc in 253 regularly transfused thalassaemic patients in relation to number of blood units received

\begin{tabular}{ccccc}
\hline Blood transfused (units) & No. of cases & HBsAg & Anti-HBs \\
\hline $0-40$ & 146 & $6(5 \%)$ & $41(28 \%)$ \\
$41-80$ & 73 & $3(4 \%)$ & $40(54 \%)$ & $4(2 \cdot 7 \%)$ \\
$>80$ & 34 & $1(2 \cdot 5 \%)$ & $29(85 \%)$ & $12 \cdot 7 \%)$ \\
Controls & 159 & 0 & $12(7 \cdot 5 \%)$ & 0 \\
\hline
\end{tabular}

This examination was made at the beginning of our study. 
patients who showed clinical or subclinical hepatitis.

$\mathrm{HBsAg}$ was found in all cases examined from 30 days before to 30 days after the onset of clinical and/ or biochemical signs of hepatitis. The number of positive cases decreased progressively in the following 7.5 months.

In general, anti-HBc appeared 30 days after the onset of clinical and/or biochemicl signs and was detectable in the serum for six to eight months. In three patients, anti-HBc was the only marker determinable in serum between the fourth and fifth months after the onset of clinical or biochemical signs of hepatitis.

Anti-HBs began to be recognisable four months after the clinical and/or biochemical onset of hepatitis; the incidence increased progressively to $99 \%$ of cases in the seventh month. Successively it was present in almost all patients during the two-year observation period.

\section{INCREASE IN SERUM TRANSAMINASES}

As can be seen in Table 2, the monthly serum transaminase determination showed very high SGPT values $(>250 \mathrm{mU} / \mathrm{ml})$ in 35 patients, who also had clinical signs of acute hepatitis; in 34 of them, HBsAg and/or anti-HBc, previously absent, was detected.

One hundred and fifty-six patients had serum transaminases ranging from 40 to $250 \mathrm{U} ; 135$ of these showed the presence of at least one of the viral markers. None of these patients had clinical signs of acute hepatitis (Table 2). Serum transaminases of less than 40 were seen in 62 patients with no viral markers in the serum.

The incidence of raised transaminase levels for a shorter or longer period of time was higher in HBV positive (approx 30\%) than in HBV negative (approx $9 \%$ ) subjects (Table 3 ).

Table 3 Follow-up of subjects with increased SGPT values in relation to $\mathrm{HBV}$ markers

\begin{tabular}{lccc}
\hline HBV markers & No. of cases & \multicolumn{2}{l}{ Raised SGPT(3 times normal) } \\
\cline { 2 - 4 } & & For $<6$ mth & For $>6$ mth \\
\hline HVB - & 22 & $2(9 \%)$ & $2(9 \%)$ \\
HBV + & 169 & $54(31 \%)$ & $55(32 \%)$ \\
\hline
\end{tabular}

HBV - = no HBV markers.

$\mathrm{HBV}+=$ at least anti-HBs present.

\section{LIVER HISTOLOGY}

The relation between HBV markers and liver biopsy findings in 52 patients who had raised SGPT for over six months is shown in Table 4. On histological examination all the 52 patients were seen to have chronic liver disease, ie, chronic persistent hepatitis $(\mathrm{CPH})$ in 20 and chronic active hepatitis (CAH) in 32.

HBsAg and anti-HBc were detectable in the serum of two patients with CPH. In the other patients, except two cases of CAH with no HBV markers, only anti-HBs was found. None had any clinical symptoms of liver disease.

\section{Discussion}

\section{INCIDENCE AND FOLLOW-UP OF B VIRUS} MARKERS

This study of thalassaemia major patients confirms previous results in thalassaemia ${ }^{1-6}$ and haemophilia patients ${ }^{13-15}$ showing a high incidence of $\mathrm{HBV}$ markers with frequencies of $\mathrm{HBsAg}$-positive subjects

Table 2 Two-year follow-up of serum transaminase in 253 children with homozygous $\beta^{\circ}$-thalassaemia major in relation to $\mathrm{HBV}$ markers

\begin{tabular}{|c|c|c|c|c|}
\hline \multirow[t]{2}{*}{ No. of cases } & \multirow[t]{2}{*}{$G P T(m U / m l)^{*}$} & \multicolumn{2}{|c|}{ No. of subjects } & \multirow{2}{*}{$\begin{array}{l}\text { Clinical signs } \\
\text { (jaundice, gastrointestinal } \\
\text { disorders) }\end{array}$} \\
\hline & & $H B V+$ & $H B V-$ & \\
\hline $\begin{array}{r}35 \\
156 \\
62\end{array}$ & $\begin{array}{l}>250 \\
\quad 40-250 \\
40\end{array}$ & $\begin{array}{r}34 \\
135 \\
-\end{array}$ & $\begin{array}{r}1 \\
21 \\
62\end{array}$ & $\begin{array}{l}+ \\
- \\
-\end{array}$ \\
\hline
\end{tabular}

* Maximum value scored.

$\mathrm{HBV}+=$ at least anti-HBs present. $\mathrm{HBV}-=$ No HBV markers.

Table 4 Histopathological findings in patients with raised SGPT for over six months in relation to HBV infection

\begin{tabular}{llccc}
\hline Histopathological findings & No. of cases & HBs Ag & anti-HBs Ag \\
\hline CPH & 20 & 2 & 19 & 2 \\
CAH & 32 & - & 30 & - \\
\hline
\end{tabular}

$\mathrm{CPH}=$ chronic persistent hepatitis.

CAH $=$ chronic active hepatitis. 
decreasing and anti-HBs-positive subjects increasing with the number of transfusions received. Anti-HBc was always associated with the presence of HBsAg, except in three patients who showed anti-HBc as the only marker of $\mathrm{HBV}$ infection. The lower incidence of anti-HBc in this study than in previous reports ${ }^{16}$ is probably related to the lower sensitivity of indirect immunofluorescence compared to RIA. Since antiHBs may transiently develop without anti-HBc after immunisation with purified non-infectious HBsAg, ${ }^{16-21}$ some of our patients, who had been transfused for many years with whole blood, could have developed anti-HBs in response to the weakly immunogenic activity of immune serum globulin containing low-titre $\mathrm{HBsAg}$ or $\mathrm{HBsAg} /$ anti-HBs complexes. However, the persistence of anti-HBs at the two-year follow-up examination is against this hypothesis. The development of HBsAg and anti$\mathrm{HBc}$ in two subjects with persistent anti-HBs is surprising. One of these patients developed acute hepatitis with persisting anti-HBs; the other became a chronic carrier with disappearance of anti-HBs positivity. These findings may be explained assuming either passive anti-HBs transmission with blood transfusion or HBV infection by a subtype different from that of pre-existing antibody.

The monthly follow-up has shown a very high incidence of subjects with acute hepatitis B which was mainly subclinical. These patients had the highest transaminase values. The follow-up of hepatitis B virus markers has shown normal $\mathrm{HBsAg}$ clearance and an immune response as demonstrated by the development of anti-HBs. In our series, clinical or biochemical evidence of acute hepatitis not associated with the development of HBV markers was rarely observed.

CHRONIC LIVER DISEASE

The incidence of chronic liver disease following HBV infection was significantly higher in thalassaemia major patients $(32 \%)$ than in non-thalassaemic subjects (roughly 10\%) (unpublished results). On the other hand, in the HBV negative group there was a low incidence of chronic liver disease, which is probably due to non-A, non-B virus infection. We used increased transaminase values as a screening test, and this may have underestimated the frequency of liver abnormalities since 3 out of 21 patients with normal liver chemistry were found to have chronic hepatitis in a liver biopsy taken during splenectomy (unpublished results). The absence of $\mathrm{HBsAg}$ and anti-HBc in the serum in almost all our anti-HBs positive patients with chronic hepatitis has two alternative explanations: the disease may be due to non-A, non-B virus(es) or to the B virus, but there was no evidence of viral replication in the serum probably due to low dose infection.

Assuming that chronic hepatitis in our patients resulted from hepatitis $B$ virus infection, it remains to be clarified why there was chronic evolution in the presence of anti-HBs. Since HBsAg has been found to be heterotypic, ${ }^{22}$ anti-HBs present in our patients could be specific for other $\mathrm{HBsAg}$ determinants. Alternatively, iron overload in the presence of low dose intact virus or viral products could be a factor in the development or perpetuation of chronic liver disease in anti-HBs positive patients.

This work was supported by grants from Assessorato Igiene e Sanità Regione Autonoma della Sardegna, NIH grant No. 1 RO1 HL 24173-01, and CNR progetto finalizzato Medicina Preventiva: Malattie Ereditarie dell'Eritrocita (MEE).

\section{References}

${ }^{1}$ Blumberg BS, Vierucci A, London WT, Sutnik AI. Association of antibodies to Australia antigen with anti$\mathrm{Gm}$ antibodies in Italian patients with thalassaemia. Nature 1972;236:28-30.

2 Vierucci A, London WT, Blumberg BS, Sutnik AI, Ragazzini F. Australia antigen and antibody in transfused children with thalassaemia. Arch Dis Childh 1972; 47:760.

${ }^{3}$ Kattamis C, Syriopoulou V, Davri-Karamouri Y, Demetriou D, Matsianiotis N. Prevalence of Au-AG and Au-AB in transfused children with thalassaemia in Greece. Arch Dis Childh 1974;49:450-3.

4 Diebold J, Camilleri JP. Foie et Affections du Sang. Paris: Masson; 1979:1,149.

${ }^{5}$ Chamfield MS, Scalise G, Economidau I et al. Immunogenetic factor in thalassaemia and hepatitis-B infection: a multicentre study. Dev Biol Stand 1975;30:257-69.

- Masera G, Jean G, Gazzola G, Novakova M. Role of chronic hepatitis in development of thalassaemic liver disease. Arch Dis Childh 1976;51:680-5.

' Papaevangelau G, Frösner G, Economidau J, Parcha S, Roumeliotou A. Prevalence of hepatitis A and B infections in multiply transfused thalassaemic patients. Br Med J 1978;1:689-91.

${ }^{8}$ Risdon AR, Barry M, Flynn DM. Transfusional iron overload. The relationship between tissue iron concentration and hepatic fibrosis on thalassaemia. J Pathol 1975;116:83-95.

9 Alter HJ, Holland PV, Purcell RH, Propper H. Trasmissible agent in non-A, non-B hepatitis. Lancet 1978;1 459-63.

${ }^{10}$ Kan YW, Schwartz E, Nathan DG. Globin chain synthesis in the alpha-thalassemic syndromes. J Clin Invest 1968 ; 47:2515-22.

11 De Groote J, Desmet V, Gedigk P et al. A classification of chronic hepatitis. Lancet, $1968 ; 2: 626-8$.

${ }^{12}$ Bianchi L, De Groote J, Desmet VJ et al. Acute and chronic hepatitis revisited. Lancet 1977;2:914-9.

${ }^{13}$ Preston FE, Underwood JCE, Mitchell VE, Triger DR, Bardhan G, Stewart RM. Percutaneous liver biopsy and chronic liver disease in haemophiliacs. Lancet 1978;2: 592-4.

${ }^{14}$ Mannucci PM, Ronchi G, Rota L, Colombo M. A clinicopathological study of liver disease in haemophiliacs. $J$ Clin Pathol 1978;31:779-83. 
${ }^{15}$ Burrell CJ, Black SH, Ramsay DM. Antibody to hepatitis B surface antigen in haemophiliacs on long term therapy with Scottish factor VIII. J Clin Pathol 1978;31:309-12.

${ }^{16}$ Spero JA, Lewis JH, Van Thiel DH, Hasiba U, Robin BS. Asymptomatic structural liver disease in hemophilia. $N$ Engl J Med 1978;298:1373-8.

${ }^{17}$ Krugman S, Hoofnagle JH, Gerety RJ. Viral hepatitis type B: DNA polimerase activity and antibody to hepatitis B core antigen. $N$ Engl J Med 1974;290:1331-5.

18 Hoofnagle JH, Gerety RJ, Ni Ly, Barker LF. Antibody to hepatitis $B$ core antigen: a sensitive indicator of hepatitis B virus replication. $N$ Engl J Med 1974;290:1336-40.

19 Purcell RH, Gerin JL. Hepatitis B subunit vaccine: a preliminary report of safety and efficacy tests in chimpanzee.
Am J Med Sci 1975;270:395-402.

${ }^{20}$ Buynak EB, Roehm RR, Tytell AA. Vaccine against human hepatitis $\mathrm{B}$. $J A M A$ 1976;235:2832-7.

${ }^{21}$ Hoofnagle JH, Seeff LB, Buskell Bales Z, Zimmerman HJ and The Veterans Administration Hepatitis Cooperative Study Group. Type B hepatitis after transfusion with blood containing antibody to hepatitis B core antigen. $N$ Engl J Med 1978;298:1379-83.

${ }^{22}$ Le Bouvier GL. Subtypes of hepatitis B antigen: Clinical relevance? Ann Intern Med 1973;79:894-5.

Requests for reprints to: Professor Antonio Cao, Clinica Pediatrica 2, Via Porcell, 1, 09100 Cagliari, Sardinia, Italy. 